\title{
ГУМАНІСТИЧНІ ПІДХОДИ ТА ЕКОЛОГІЗАЦІЯ КУЛЬТУРНО-ІСТОРИЧНОЇ ПАМ'ЯТІ В ПРОЦЕСІ ПІДГОТОВКИ МАЙБУТНІХ ІНЖЕНЕРІВ-ПЕДАГОГІВ НА ПРИКЛАДІ ВИВЧЕННЯ КОНКРЕТНИХ ІСТОРИЧНИХ ФАКТІВ
}

\author{
Аксакова Н. О., \\ кандидат історичних наук, доиент, Навчально-науковий професійно-педагогічний інститут \\ Української інженерно-педагогічної академії, Бахмут, Украӥна \\ DOI: https://doi.org/10.31435/rsglobal_conf/25012021/7354
}

\begin{abstract}
The article considers the introduction of a humanistic approach and restoration of cultural and historical memory in the process of training future engineers-teachers to study specific historical examples, namely the Holocaust, which is the cornerstone of the memory of World War II. Awareness of the tragedy of the nation that suffered genocide during World War II is a need to avoid future violations of human rights on racial, religious, ethnic grounds - one of the main tasks of training a specialist of the future. Holocaust remembrance is essential so that our children are never victims, executioners or indifferent observers. The author cites a specific example of a tragic historical legacy, the Holocaust in Bakhmut, when 3,000 Jews were buried alive in cell alabaster at the champagne factory, as an example of the inhuman policies of the Nazis.
\end{abstract}

Keywords: education, tolerance, genocide, repressions, Holocaust, World War II, German occupation, Bakhmut.

Вступ. Коли ми говоримо про сучасне суспільство, то розуміємо, що це складна етнічна система, що містить кілька тисяч етнічних спільнот, різноманітних та унікальних.

Проблеми сучасного суспільства полягають не тільки в расизмі, тероризмі, а також у тому, що ідеї громадянськості і прав людини замінюються етнічними, національними, релігійними суперечками. Йде жорсткий поділ - «ми» і «вони», який входить в основу всіх екстремістських ідеологій. Після 1945 р. у світі було ще близько 160 війн, в яких загинули десятки, сотні, мільйони; люди продовжують гинути і зараз. Складність взаємин в сучасному суспільстві полягає в небажанні багатьох приймати інших, ким вони $\epsilon$, а також нести відповідальність за свої вчинки.

Сучасна система освіти має упереджувати будь-які прояви нацизму, гноблення, пригнічення. Досягнути цього допоможе екологізація культурно-історичної пам'яті сучасних підлітків і молоді, так як «культурна пам'ять» формує уявлення людини про світ, під її впливом складається ціннісна система, регулюються норми соціальних відносин, здійснюється зв'язок 3 історичним минулим i вибудовується перспектива майбутнього розвитку, приймають упорядкований характер різноманітні відносини і зв'язки народу з навколишнім світом.

У сьогоднішньому технологічному ритмі далеко за рамками залишаються теми, викладання яких вимагає особливого трепету і уваги з боку будь-якого педагога. Адже від того, яким буде пояснення таких легких і, водночас, важких слів як «толерантність», «тероризм», «репресії», «Голокост», «геноцид» та ін., залежить майбутнє не лише нашої країни, а й усієї планети. Вивчення страшного минулого - це не тільки збереження пам'яті про загиблих, а й одна з умов виживання сучасної людини.

Осмислення Голокосту можливо як у широкому історичному контексті, у зв'язку з тими подіями, процесами і явищами, які зробили можливим масове і цілеспрямоване винищення цілого народу, так і при вивченні конкретних прикладів злочинів нацистів у містах України, які не є об'єктами значних досліджень та не широко висвітлені у наукових працях.

Мета роботи. Донести інформацію про Голокост на території м. Бахмут, коли в алебастровому забої заводу шампанських вин 3000 євреїв були заживо замуровані в камері № 46, як приклад нелюдської політики нацистів. Саме ця інформація стане в нагоді педагогам та історикам при впровадженні гуманістичних підходів та відновленні культурно-історичної пам'яті сучасної молодів процесі отриманні інженерно-педагогічної освіти (i не лише іiі): 
вихованні почуття співчуття чужому горю, сприянні формування толерантності, соціальної активності, громадянської відповідальності, підвищенні загального рівня толерантності, формуванні толерантної свідомості на прикладі історії Голокосту, гуманного ставлення до людей взагалі, незалежно від їх національної, расової або релігійної приналежності.

Методи дослідження. Загальнонаукові педагогічні принципи, принципи історизму, наукової об'єктивності, системності та верифікації, світоглядного плюралізму. Для обробки матеріалу використовувались порівняльно-історичний, аналітичний, статистичний, проблемнохронологічний, системний, узагальнюючий методи.

Результати дослідження. Місто Бахмут (з 1924 до 2016 - Артемівськ) - найстаріший історико-культурний центр Донбасу. Він впевнено займає провідне місце у Всеукраїнській мережі міст стійкого розвитку, вважається одним з найкрасивіших у країні. Культура Бахмута має глибоке коріння, славиться своїми науковими, виробничими, культурними закладами, що мають багатий досвід відродження й розвитку культурної спадщини.

Не менш відомим є завод шампанських вин «Артвайнері» - найбільше підприємство в Східній Європі з виробництва ігристих вин класичним пляшковим методом. У 1954-му році були зроблені перші 500 тисяч пляшок ігристого шампанського. Напій був настільки високої якості, що незабаром став кращим і самим дефіцитним ігристим шампанським в СРСР.

Але за усім цим ховається одна 3 найстрашніших сторінок в історії міста Бахмут живцем замуровані близько 3000 мирних жителів в алебастровій штольні «Артвайнері», відомої під назвою «Камера № 46».

В Бахмуті (Артемівську) жили люди різних національностей, у тому числі і євреї, до революції євреєм був кожен п'ятий житель Бахмута, напередодні війни їх кількість становила (в 1939 р.) - 5299 людини.

Між громадянами були добросусідські відносини, взаємоповага, толерантне ставлення між конфесіями, увага до національних особливостей і культури. В місті була єврейська школа i «єврейська лікарня», єврейське кладовище. У народному домі були три національні аматорські трупи: українська, російська та єврейська.

Усе змінилося в період тимчасової німецько-фашистської окупації. 31 жовтня 1941 року діючі частини німецької армії окупували місто Артемівськ. Вірні своїй політиці німецькофашистські загарбники встановили для населення рабський режим, повсюдно широко застосовуючи обурливе насильство, грабіж і винищення громадян.

3 цього моменту в місті почалася найбільша трагедія, найбільший злочин ХХ століття ГОЛОКОСТ.

Почалася паспортизація жителів міста, вперше докладались відбитки пальців до цих документів.

Також було введено Берлінський час: повсюдно перевели його на 2 години вперед.

«Німці розділили населення міста на українців - їм дозволялося ходити по місту до 22 годин, росіян - до 19 годин і євреїв, яким після 16 не дозволялося виходити з дому...» [1, с. 34].

Комендантом в місті був призначений ставленик зондеркоманди майор фон Цобель, який планомірно виконував завдання Вермахту по знищенню євреїв. Цобель підібрав собі команду зі зрадників: призначив начальником поліції Бахмутського повіту Васильєва; міським головою Головню (колишнього вчителя німецької мови міської школи) та інших пособників $\mathrm{i}$ зрадників. Цобелем і його посібниками був розроблений план повного знищення євреїв.

Призначили місце, час, спосіб оповіщення. Були поставлені завдання, визначені заходи по захопленню всього єврейського населення. 19 листопада 1941 р. Цобель видає наказ, в якому зобов'язує всіх євреїв зареєструватися в комендатурі, носити на правій руці пов'язку. 22 листопада комендант міста видав наказ про негайну перереєстрацію всього єврейського населення чоловічої статі. У наказі говорилося, що всі євреї-чоловіки повинні до 9 години з'явитися в комендатуру, звідки їх будуть направляти на важкі роботи. Після цього наказу всі євреї чоловічої статі, люди похилого віку і підлітки посилалися німцями на найважчі роботи. Ніхто не міг здогадатися, що через тиждень відбудеться страта приречених в алебастровій шахті, в одній з іiї гірничих виробок, відомої під назвою «Камера №46». 7 січня 1942 року по місту розклеїли оголошення, опублікували його в газеті «Бахмутський вісник» [2]. 
«Звернення до євреїв Бахмута»

1. 3 метою ізольованого розміщення, всі євреї м. Бахмута, чоловічої і жіночої статі, різного віку, повинні в п'ятницю 9 січня о 8 годині ранку зібратися в приміщенні колишнього НКВС в парку.

2. Кожній особі дозволяється мати з собою багаж в 10 кг, а також запас продовольства на 8 днів.

3. На вищезгаданому місці збору повинні бути здані ключі від квартир із зазначенням прізвища та адреси (вулиця, № будинку) власника квартири. Вхід в порожні єврейські квартири або вилучення будь-яких предметів звідти з боку цивільного населення розглядається як грабіж і карається смертю.

4. Протидія даній постанові, особливо неточна явка або відсутність на зазначеному місці збору, карається найсуворішим чином. (За неявку - розстріл)

5. Свреї, які перебувають де-небудь на роботі, повинні звільнитися.

Міський голова.

Бахмут 07.01.1942 p.

9 січня на вулицях можна було побачити багато відомих лікарів, вчителів та інших жителів міста.

3 «Книги Скорботи» міста Артемівська: «...Йшли до призначеного місця відомі лікарі, вчителі, ремісники та інші жителі міста. Багато було старих, жінок з малолітніми і грудними дітьми на руках. Деяких людей похилого віку родичі везли на візках, саночках. Дітей було багато, так як до війни єврейські сім'ї були, як правило, багатодітними. Йдуть по Харківській вулиці невинні люди. Йде до призначеного пункту збору сім'я Самуїла Камінського, що складається з 9-ти осіб. Самуїл тримає на руках 4 річного сина Сашка, дружина Лідія тримає на руках хлопчика Валерія, йому 1год 5 місяців. Він тримає в руках брязкальце. Інші їхні діти тримаються один за одного біля батьків: Белла -6 років, Тамара -8 років, Юра -10 років, Лія - 12 років. 3 ними сестра дружини Самуїла, російська жінка. Йде до місця призначення Галина Фрейгерова 3 5-ма дочками. Одну матір тримає на руках, інші злякано тримаються один за одного. На саночках онук Шнейдера везе паралізовану 80 річну бабусю. Йде до місця призначення бухгалтер банку Дєєва. Вона єврейка, з нею їі чоловік, росіянин за національністю. Він хоче розділити долю своєї дружини. Чи знали приречені, куди вони йдуть, що їх чекає?» $[3$, с. 6$]$.

Більшість 3 них вірили, що їх переселятимуть в інше місце. Все ж таїлася надія, що німці цивілізований народ, значить не здатний на зло.

Навіть серед суцільного зла знайдеться просвіт. Зі спогадів очевидців і серед фашистів були люди: «...У квартирі Рози Турків, їх двір був поруч з нашим, стояв німець. Він всерйоз захопився старшою сестрою Рози, допомагав їм продуктами. Одного разу, коли йому треба було $з$ його частиною їхати на фронт, він по великому секрету сказав Любі: «Я тобі, на жаль, нічим допомогти не можу, я йду на фронт, але відкрию тобі секрет - йдіть, куди можете, вас, як євреїв, знищать». Тоді ще не вірилося, що подібне трапиться, та й бігти нікуди було, ні родичів в інших містах, ні коштів десь ховатися не було» [4, с. 16].

В збірному пункті кожному пропонувалося увійти в приміщення для реєстрації. Звідти ніхто вже не вийшов. У підвали будівлі колишнього НКВС було загнано понад 3-х тисяч осіб, де три дні 9, 10 і 11 січня 1942 утримувалися без води і їжі.

Крики і стогони людей були чутні далеко в місті. Простягаючи руки крізь грати підвалів, вони кричали: «пити, пити, снігу дайте!» Дітвора збиралася біля підвалів і кидала грудки снігу у вікна, але німецькі вартові і поліцейські за це били дітей. Через кілька днів крики і стогони змовкли.

«В ніч 310 на 11 січня 1942 року кати почали виконувати свій зловісний план - карати приречених. Ніч наповнилася плачем і криками. Частину людей з підвалів вивезли в газових душогубках у піщані кар'єри. Інших в'язнів з підвалів на світанку 11 січня занурили у вантажних машинах вивезли до місця страти - в алебастрові розробки. Люди були виснажені. Багатьох людей похилого віку в машини заносили на руках. Приречені люди кричали, плакали, їх палицями заганяли в машини. Привезли людей до входу в шахту. Знесилені, виснажені вони ледве йшли, деяких несли на руках. Молоді люди сивіли на очах. Людей гнали до зловісної камери №46 - місця страти. До цього місця ведуть підземні коридори. I страшно подумати, як йшли приречені. Вони знали, що їх чекає попереду, тому шлях у підземеллі їм здавався коротким. Та навіть якби їм довелося йти через всі коридори артемівських катакомб і через всі печери і лабіринти світу, все одно, шлях їм здавався б занадто коротким; вони здогадувалися, що їх чекає в кінці шляху» [1, с.47]. 
11 січня 1942 р. відбулася страта приречених. Довго звідти чулися стогони, плач.

Ризикуючи життям, жителі Артемівська, наражаючись на смертельну небезпеку, рятували приречених. Зі спогадів Людмили Урди: «Багато жителів міста, наражали себе на небезпеку, вкриваючи у себе євреїв. Коли на нашій Володимирській вулиці йшла процесія, ми, дітвора, вишикувалися біля паркану Діни Сни, нашої подруги. Її мама схопила єврейську дівчинку і зникла за хвірткою. Був смертельний ризик, всю окупацію утримувати дитину в напівголодній родині, але ніхто не видав цю таємницю. Сім'я Д. В. Плигінової врятувала від смерті єврейську дівчинку Муру, батьки якої були страчені. Софія Скібіна і Ксенія Чистякова приховували у себе єврейського хлопчика Толю Вайнштейна. Лікар Іонів врятував багатьох євреїв, віддаючи їм паспорти померлих російських жителів. Викликом фашистам була діяльність гордої, величної жінки, лікаря-хірурга Сари Михайлівни Шапіро. Вона відкрито лікувала поранених радянських воїнів. В 1943 році фашисти ії розстріляли» [5].

Незважаючи на смертельну небезпеку жителі міста, виявляли людяність, не боячись протистояти загарбникам, залишаючись хоробрими і відданими своїм співвітчизникам.

5 вересня 1943 Артемівськ був звільнений від німецьких окупантів, 22 місяці фашистської окупації Артемівська не пройшли безслідно, гітлерівцями були вбиті 15 тисяч мирних городян.

Коли місто було звільнене від окупантів, була створена Державна комісія 3 розслідування звірств фашистів в період окупації. Комісією були розкриті такі злочини, які люди не могли собі уявити. Гітлерівці разом зі своїми підручними поліцаями знищували ні в чому не винних людей.

16 вересня 1943 р. були виявлені мешканці міста, розстріляні німецькими бандитами i замуровані в камері шахти №46 Алебастрового комбінату.

Зі спогадів гвардії підполковника Бобильова Максима Іларіоновича:.. Люди зголодніли і в буквальному і переносному сенсі. Вони не питали, скільки їм заплатять, а працювали самовіддано, одержимо, і місто вставало з руїн і попелу. На третій або четвертий день після звільнення хтось із робітників прийшов і розповів про звірства фашистів. Була створена комісія 3 розслідування німецьких злодіянь. Розкрилися такі злочини, про які ще не чули. I ось, коли комісія майже всі могили Артемівська обстежила, підійшов до мене робочий Алебастрового заводу і запропонував обстежити кар'єр Алебастрового комбінату. Він сказав: «Куди поділося єврейське населення, кілька тисяч? Адже ми їх не знайшли, і крім того я кілька разів бачив машини, навантажені людьми, які йшли в кар'єр».

16 вересня комісія в повному складі, активісти, озброєні факелами і відрами з мазутом, вирушили на пошуки. Обстежуючи шахти Алебастрового комбінату і пройшовши з факелами близько кілометра під землею, комісія виявила закладену цегляною стіною шахту № 46. Пробили стіну, освітили факелами, увійшли, і... дихання перехопило від моторошного видовища. (Див. додаток 1 фото 1)

Що ми побачили? Величезний, близько 1000 квадратних метрів, підземний зал і направо від нього нескінченний, що губиться в мороці коридор, наповнений трупами. Тільки вузенька доріжка, далі пройти неможливо - всюди трупи і трупи. Я, насилу просуваючись, щоб не наступити на них, вдивлявся в обличчя. Їх тисячі! Вони муміфікувалися... Далі в штольні були виявлені голі трупи; це, мабуть, розстріляне циганське населення міста. Після огляду, складання акта про звірства фашистських нелюдів в Артемівську, я поїхав наздоганяти армію, яка далеко йшла на Захід.

Прибувши в армію, я тут же передав в армійську газету матеріал про звірства фашистів в Артемівську і вирушив по дивізіям, полкам і батальйонам розповідати бійцям, що бачив в Артемівську. Треба було бачити тоді наших бійців, в грудях кожного клокотала ненависть до фашистського кодла. Прийде час відплати, і жоден фашистський розбійник не утече від відповіді [3, с. 49-51]. У лютому 1944 року газета «Артемівський робітник» інформувала читачів про камеру смерті заміткою « вбивці»: «Ця жахлива історія була розкрита в перші дні після звільнення міста, у вересні 1943 року. Робочі алебастрової шахти разом з командою мінерів пішли під землю обстежити шахту з метою розмінування. Обстеження і розмінування вже наближалося до кінця, як раптом в одній $з$ найдальших галерей, освітленій нерівним світлом смолоскипів, люди помітили штучну цегляну стіну. Проробивши за допомогою ломів щілину, робітники і бійці через вузький прохід проникли в замуровану печеру. При світлі смолоскипів вони побачили кошмарну картину, 
про яку зі здриганням будуть згадувати все своє життя. Величезна печера в кілька сотень квадратних метрів була суцільно завалена людськими трупами, залишилася вільною тільки вузька доріжка, далі пройти було неможливо - всюди трупи і трупи.

Спеціально створена комісія 3 лікарів і представників громадськості міста точно встановила, що в камері шахти було замуровано три тисячі громадян, розстріляних i закатованих німцями. Ці жертви були схоплені в січні 1942 року, коли кровожерливі фашистські кати почали масове винищення євреїв. Суха замурована камера шахти зберегла трупи людей. У пам'яті людей, які бачили цей кошмар, до кінця життя запам'ятається труп старого, який, гинучи, думав про своїх двох внучатах: він дбайливо обійняв їх і так назавжди застиг 3 онучатами, що припали до його мертвого тіла. Тут же лежала мати 3 притиснутим до зотлілого грудей дитячим трупом; інша мати міцно притиснула кістлявими руками немовляти. Двоє малюків, років 5-6, одягнені в теплі пальтечка, стоять на колінах, уткнувшись голівками в дідові ноги, інвалід з милицею під пахвою і багато інших» [6].

Згідно з Актом, представниками Надзвичайної Державної Комісії по встановленню злодіянь німецько-фашистських окупантів 3 жовтня 1943 р. був проведений огляд алебастрових кар'єрів і встановлено наступне: «В 2 кілометрах на схід від міста Артемівська в тунелі кар'єрів алебастрового заводу на відстані 400 метрів від входу є невеликий отвір, замурований цеглою. Після розкриття цього отвору виявлено продовження тунелю у вигляді вузького проходу, що круто піднімається вгору і закінчується широкої овальною печерою до 20 метрів завдовжки, 30 метрів ширини і 3 - 4 метрів висоти.

Вся печера заповнена трупами людей; лише невеликий простір біля входу і вузька смуга в центрі іï вільні від трупів. Всі трупи тісно притиснуті один до іншого і повернуті спинами до вхідного отвору печери. Трупи настільки близько прилягають, що на перший погляд являють собою суцільну масу тіл, сплетених один з одним. Задні ряди навалено на передні, притиснуті до стін печери, і нагромаджені в кілька рядів, застиглих в стоячому або уклінному положенні тіл.

Завдяки особливостям місцевих умов (відносній сухості повітря, низькій і рівномірній температурі, пористому дну печери) відбулося муміювання трупів і більшість 3 них відмінно збереглося.

Одяг на всіх трупах зимовий, пальто та інше верхнє вбрання застебнуті, голови і шиї у більшості закутані.

У більшості трупів помітні білі пов'язки на лівому рукаві пальто з вишитими або намальованими на них «зірки Давида». На деяких трупах строкатий і яскравий одяг, який зазвичай носять цигани.

Переважають в основному трупи жінок і дітей різних вікових груп. Зустрічаються також трупи інвалідів 3 милицями і палицями.

Виходячи $з$ площі печери і 2-3-слойного розташування трупів, комісія встановила, що в печері знаходиться близько 3000 трупів.

В печері виявлено також ручні валізи, сумки від протигазів, вузлики 3 домашніми речами першої необхідності і невеликою кількістю провізії.

На підставі огляду місцевості, медичного огляду трупів та опитування свідків 3 місцевого населення комісія встановлює, що тут було масове знищення близько 3000 радянських громадян - жінок, дітей, людей похилого віку та інвалідів як євреїв, так і громадян інших національностей. Їм було заявлено німецьким командуванням, що їх відправляють на інше місце проживання. Замість цього їх пригнали в печеру, де й була звіряча розправа над ними. По мірі того як печера наповнилось людьми, вони розстрілювалися в стоячому або уклінному положенні, приганялась інша група, яку вбивали на купі трупів і вмираючих, тіла убитих нагромаджувалися в кілька рядів.

Комісія вважає, що серед загиблих були і поранені, живцем замуровані в цій печері німецько-фашистськими окупантами.

Комісія встановлює, що в артемівських алебастрових кар'єрах було розстріляно і живцем замуровано близько 3000 радянських громадян» [4, д. 19].

Вчитуючись в текст Акта з'являється безліч питань: «...зал площею в кілька сот кв. метрів, завалений величезною кількістю трупів / не менше 2-3 тисяч, розташованих в порядку по обидві сторони доріжки, яка тягнеться на відстань 20-25 метрів, впираючись в глуху 
стіну. Трупи як би навалені один на одного, особами зверненими вниз з піднятими комірами, 3 притиснутими на грудях руками...».

Що це за доріжка, що розділила жертв на дві частини? Чому трупи притиснуті до стін печери?

Зі спогадів В. М. Кийченко, розстрілювали далеко не всіх «...останніх людей, яких виносили нагору, це тих, хто був 3 протилежного кінця камери на 4-му районі. Вони були 3 кульовими пораненнями і навколо них валялися гільзи. Очевидно ті, яких загнали останніми, намагалися вирватися, розуміючи, що їх чекає, а їх розстрілювали, поки не замурували стіну...» [1, с. 52].

Чому обличчя всіх жертв були звернені обличчям вниз, чому жертви - 3 піднятими комірами, складається враження, що люди ховали обличчя чомусь притиснутими на грудях руками?

У матеріалах судового процесу над групою зрадників і зрадників-душогубів, підлих наймитів німецьких кровопивць (м. Артемівськ, 15 - 18 січня 1944 р.) стверджувалося, що «дослідження останків довело, що значна частина загнаних у камери були живцем замуровані i загинули від удушення і голоду» [4, с. 19$]$.

Висновок комісії приголомшливий: «загальне враження комісії таке: люди живцем загнані в печеру, замуровані і отруєні задушливим газом.

Цілком ймовірно газ пущений через отвір в замурованій стіні довгим струменем і в жахливому страху розділив людей на 2 половини, залишивши вільним прохід».

Сьогодні шахтарі підтверджують, що зробити подібне в 1942 р. була технічна можливість.

Про удушення газом мирних людей поговорювали і самі окупанти. «У квартирі головного лікаря Любимової фельдфебель міського інтенданства Герберт Шобель розповідав про способи страти нещасних жертв розгнузданого фашизму. Дорослих, за його словами, душили газами, а дітям мазали верхню губу якоюсь отрутою. Про це розповідав у цій же квартирі і лікар дивізії «Адольф» баварець Моріс Вательс. Цей гітлерівець ще не втратив залишок людського почуття i заявив: «Це середньовіччя, це ганьба для німецької нації» [5, с. 12].

Для подальшого поховання, необхідно було, щоб місцеві жителі змогли впізнати серед трупів своїх рідних, знайомих. Трупи треба було винести з шахти. Викриті пособники фашистів - поліцаї, виносили 3 шахти трупи. Трупи розстріляних були оглянуті і вивезені з шахти на площу біля Кераміко-трубного заводу, де були покладені рядами для огляду всім населенням м. Артемівська та прилеглих селищ. Для огляду і впізнання трупи знаходилися на площі протягом трьох діб.

Зі спогадів заслуженого вчителя України Марка Володимировича Габелева: «...Ганна Єфімцева, сестра безвісти зниклої, мабуть, не подумавши, взяла мене, шестирічну дитину, за руку і повела туди. Те, що я побачив, було просто жахливо, витягнуті трупи зайняли площу поля до 10 гектарів. Артемівці та мешканці прилеглих сіл потягнулися до цього поля смерті. Стогін і плач стояли над полем. Дивишся на «культурну місію, виконану німцями, на вчинене двоногими звірами в нашому місті - і мороз по шкірі... Потрясіння, яке не покидає мене все життя. Коли у мене запитують, Чи бачив я війну, відповідаю: бачив!»

По підрахунку трупів виявилося: усього було розстріляно і замуровано в камері № 46 3000 радянських громадян - жінок, дітей, людей похилого віку та інвалідів як євреїв, так і громадян інших національностей.

Усього було упізнано 408 осіб. Міському штабу «Пошук» вдалося встановити понад 1,5 тисячі імен загиблих. Всі вони занесені в міську «Книгу скорботи». У різних документах зустрічається різнобій в датах, в цифрах, що визначають кількість жертв. Тривала війна - i, напевно, було не до ретельних досліджень. Головною метою в той час було віддати належне невинно убієнним, знайти і покарати винуватців злодіянь.

3 судового процесу над фашистськими катами: «Зрадників Батьківщини, мерзенних пособників німецьких катів - до відповіді!

Сьогодні (15 січня 1944 року) в місті Артемівську починається судовий процес над групою зрадників-душогубів, підлих наймитів німецьких нелюдів.

Військово-польовий суд Н-ської частини приступає до розгляду справи групи зрадників Батьківщини, активних пособників німецьких катів, безпосередніх учасників катувань радянських громадян міста Артемівська в чорні дні німецької окупації, колишніх службовців німецької поліції м. Артемівська: Кумова Федора Гавриловича, Саламатіна Івана Васильовича, 
Лагеря Івана Івановича, Пуха Павла Семеновича і Дружнова (він же Друженко) Сергія Семеновича» [10, с.150-160].

Під перехресним допитом прокурора, за показаннями підсудного Кумова і свідка Медведєва з'ясувалося, що Лагерь був не просто бездіяльним спостерігачем горя радянських людей, а що він ніс озброєну охорону над приреченими до смерті старими, жінками і дітьми, зігнанними в сад не без його участі, та особисто бив палицею цих жінок і дітей, які не бажали сідати в машини для відправлення на розстріл».

Військовий кореспондент Південного і 3-го Українського фронтів капітан А. Левада, присутній на цьому процесі, писав: «...Він (Кумов), як міг допомагав німцям у жахливій розправі над двома тисячами громадян Артемівська в січні 1942 р., він сам тоді наказав заарештувати групу радянських людей. Він особисто перевіряв, чи надійно охороняють скажені собаки-полицейскі. Він чув, як кричали жінки і діти в зловісному підвалі, прохаючи дати їм хоч краплю води, бачив, як волокли німці цих людей з підвалу на розстріл, бачив, як босими ніжками крокували по січневому снігу приречені на смерть діти...» [9]. Військово-польовий суд визнав доведеною вину всіх підсудних у злочинах, передбачених частиною 1-го Указу Президії Верховної Ради СРСР від 19 квітня 1943 року, і ЗАСУДИВ: підсудних Кумова Федора Гавриловича, Саламатіна Івана Васильовича, Лагеря Івана Івановича, Пух Павла Семеновича i Дружнова (він же Друженко) Сергія Семеновича - до страти через повішення.

Пам'ять про загиблих ніколи не забудеться, навіть незважаючи на те, що «...у 19431944 pp. та в наступні десятиліття факти Голокосту в силу офіційної державної юдофобії маскувалися терміном «загиблі мирні жителі» (євреїв як би і не існувало!)».

Але не дивлячись на всі спроби приховати звірячі злочин проти невинного народу, пам'ять про них ніколи не зів'яне.

Цінність людини пізнається лише після його смерті, але життя буде і залишається безцінною.

У пам'ять про загиблих 12 січня 1999 року на місці камери № 46 було відкрито Меморіал. Стіну, де вмонтований Меморіал, назвали «Стіною плачу». Чудесним чином після відкриття Меморіал «заплакав». За роки роботи винороби Бахмута в жодній штольні або галереї ні разу не бачили крапель вологи на стелях і стінах. Солонуваті краплі, що людські сльози по безвинно загиблим, струмують по пам'ятнику.

Ініціаторами спорудження меморіалу на місці камери № 46 стали Артемівська міська Рада народних депутатів, Артемівський завод шампанських вин та Артемівський єврейський благодійний фонд «Хесед-Зікарон». Меморіал являє собою скульптурне зображення жінок, що символізує горе, страждання, скорботу. На грудях - дзвони, які не дають пам'яті заснути.

Щорічно, 11 січня біля Стіни плачу в алебастровою штольні «Артвайнері», вшановують пам'ять євреїв, по-звірячому замурованих фашистами в покинутій шахті алебастрових кар'єрів, в пам'ять про цю страшну трагедію на мітингу-реквіємі запалюють свічки, покладають квіти і читають поминальну молитву.

До Стіни плачу, як і до Єрусалима, за єврейською традицією люди кладуть маленькі камені: «Живим - живе, мертвим - мертве...»

Стіна плачу - це святиня. Прах загиблих у всьому світі і в нашому невеликому місті закликає до розсудливості, до дружби між народами, скріпленої загальними братськими могилами.

Висновки. У статті розглянута найстрашніша та найтрагічніша подія в історії людства Голокост, який $\epsilon$ наріжним каменем пам'яті про Другу світову війну. Саме ця історична подія спонукає до загального переосмислення власного історичного наративу, переосмислення минулого та вироблення нових концепцій, більш відповідних потребам сучасної політичної нації.

Усвідомлення трагедії нації, що піддали геноциду в роки Другої світової війни $\epsilon$ необхідністю уникнути в майбутньому порушення прав людини на расовому, релігійному, етнічному грунті.

Пам'ять про Голокост необхідна, щоб наступне покоління ніколи не було жертвами, катами або байдужими спостерігачами. 


\section{ЛІТЕРАТУРА}

1. Черепков В. Ф. Камера смерти. - К.: УАИП «Рада», 2016. - 136 с. - (Серия «Эхо войны»).

2. Бахмутский вестник. - 1942. - № 43. - 6 июня.

3. Артемовский Бабий Яр: сборник / сост. Д. Л. Вигдергауз; ред. М. В. Габелев. - Артемовск: [б.и.], 2000. - 55 с.: ил.

4. Корнацький I. А. Місто Артемівськ і Артемівський район у $1941-1943$ роках: окупаційний режим i примусова праця / / Заповідаємо вам пам'ять. - С. 19.

5. Бахмутський часопис, № 3 - 4, Артемівськ, 1995 р.

6. Акт по расследованию зверств немецких оккупантов в городе Артёмовске. ГДДО, Фп-17, on. 4, д. 19 , лл. $1,2$.

7. Замковой В. П. Рукопись романа «Человек, оставшийся в живых». // Бахмутский краеведческий музей, КП-12220/ДС-2173.

8. Газета «Артемовский рабочий», Александр Левада, «Паук - кровосос». 17 января 1944 г.

9. «Нюрнбергский процесс» (сборник материалов в 8 томах), М., «Юридическая литература», 1991, т . 5, раздел «Преступления против мирного населения», с. $159-160$.

10. «Артёмовск в борьбе с немецкими захватчиками», ГАДО, Ф. 5000, оп. 1, д. 12.

11. АКМ. Відділ фондів, ф.60, спр. 3.

12. Артёмовск в оккупации. (Зверства немецких бандитов в городе Артёмовске), ГДДО, фонд П-5000, оп. 1 , д. 126.

13. Бахмутский краеведческий музей, КП-12220/ДС-2173.

14. ГАДО. Библиотечный фонд. Альбом фотографий, инв. № 127.

15. Донеччина в роки Великої Вітчизняної війни 1941-1945: відомі та невідомі сторінки історії. - С. 127.

16. Заповідаємо вам пам'ять /: місто Артемівськ і Артемівський район в роки нацистської окупації (1941 - 1943): науково-документальне видання / укладачі С. М. Сикварова, I. А. Корнацький, с. 121.

17. Карел Беркгоф. Жнива розпачу. Життя і смерть в Україні під нацистською владою / Беркгоф Карел. - Київ: Критика, 2011. - 455 с.

18. Катастрофа украинского еврейства 1941-1944 гг.: энцикл. справочник / А. И. Круглов. - Х.: Каравелла, 2001. - 376 с.

19. Кошкина (Велишкевич) О. С. По ступенькам памяти. Артёмовен, 2000. - с. 22.

20. Куромія, Гіроакі. Свобода і терор у Донбасі: Українсько-російське прикордоння, 1870-1990-і роки. Пер. 3 англ. Г. Кьорян, В. Агеев; Передм. Г. Немирі. - Київ: Видавництво Соломії Павличко «Основи», 2002. -510 с.

21. Матеріали з Фондів Бахмутського краєзнавчого музею, Фонд № 78 Справа 1.

22. Татаринов С. Й., Федотов С. А. Штетл-Бахмут - феномен еврейского народа в Донбассе. Историкокультурологический сборник. -Х.: ЧИПП «Слово» 2013, 186 стр. 